\title{
KAJIAN INSTRUMENTASI DAN ORGANOLOGI GENDANG BELEQ SANGGAR MERTAQ MI LOMBOK TENGAH NUSA TENGGARA BARAT
}

\author{
Gde Agus Mega Saputra \\ Pengajar di Prodi Sendratasik Universitas Nahdlatul Ulama NTB \\ Email: gdeputra88@gmail.com|085253772588
}

\begin{abstract}
It is of absolute importance, to maintain the art of Gendang Beleq when it comes to its sustainability among the Sasak culture. Therefore, being the identity of Lombok Island in West Nusa Tenggara, the awareness of the people possessing such art is highly demanded, in order to safeguard its advancement. It means that when people do not realize that Gendang Beleq is an asset or representation of their culture, there are many uncertainties regarding the future of its existence. The most obvious thing is the lack of reference related to the explanation of the names of the instruments contained in this art, as well as the organology of Gendang Beleq that has never been published in the form of research journals and books. This paper is more of an effort to explore and understand the existence of each instrument in the Gendang Beleq ansamble group. To capture the value of knowledge and overall description related to Gendang Beleq's art in order to obtain data as desired, the time of the research is conducted using a qualitative approach. Organological studies are used to understand or explore the essence of the presence of each instrument. The researcher as the main instrument was in direct contact with the object of study. Various efforts such as in-depth interviews, documentation, direct involvement in art activities, and conducting in-depth dialogues with actors in this case are carried out to obtain thorough information related to the object of study.
\end{abstract}

Keywords: Instrumentation, Organology, Gendang Beleq Mertaq Mi Setanggor.

\section{Pendahuluan}

Gamelan Gendang Beleq cukup ikonik dalam kehidupan masyarakat Sasak, karena merupakan salah satu bentuk kesenian tradisi yang terdapat di Lombok, Nusa Tenggara Barat. Sebagai salah satu produk budaya, keberadaannya merupakan kebanggaan masyarakat untuk dijadikan sebagai identitas budaya. Entitas kesenian itu seringkali menghadirkan keterwakilan masyarakat Sasak dalam konteks interaksi. Keberadaannya yang khas ketika menghadirkan permainan gendang yang berukuran besar, dibalut dengan berbagai rupa ekspresi gerak estetis tentu saja menarik untuk mewacanakan citra Lombok. Hal ini tampak bahwa produk seni menjadi gagasan awal penulis dalam mengamati fenomena sosial kultural masyarakat Sasak dengan berbagai dialektikanya.

Gencarnya mengusung Gendang Beleq dalam berbagai wacana citra tentang Lombok, tampaknya tidak sepadan dengan geliat kehidupan kesenian itu dalam masyarakat. Meski beberapa upaya telah dilakukan seperti halnya memasukkan Gendang Beleq ke dalam aktivitas pendidikan formal, penyelenggaraan festival dan kompetisi antar daerah, akan tetapi hal itu dirasa tidak cukup untuk kembali mengangkat gairah kehidupan kesenian ini. Kekhawatiran akan kemunduran atau kepunahan kesenian ini mulai dirasakan baik oleh pelaku ataupun masyarakat Lombok pada umumnya.

Mempertahankan keberadaan Gendang Beleq untuk terus ada dan berkembang, tentu saja 
akan sangat sulit dilakukan. Ketika masyarakat pemiliknya dengan segenap stake holder tidak ada suatu upaya bersama dalam kerangka sadar untuk memajukan kesenian ini. Seandainya terdapat upaya untuk mengembangkan kesenian ini tentu saja tidak akan memberikan dampak apapun, ketika selera masyarakat telah berubah, atau muncul pandangan bahwa Gendang Beleq tidak lagi sesuai dengan kondisi zaman. Artinya bahwa akan terjadi banyak kemungkinan di masa mendatang, terkait dengan keberadaan kesenian ini.

Upaya antisipasi terhadap berbagai kemungkinan terjadi pada kesenian Gendang Beleq di masa mendatang penting untuk dilakukan. Beberapa upaya dapat dilakukan, salah satunya dengan melakukan kajian awal seperti instrumentasi maupun pemahaman organologi bagi masyarakat Sasak sekaligus melakukan perekaman secara menyeluruh dan komprehensif baik dalam berbagai media seperti halnya tulisan, audio, visual(foto), dan audio visual (video). Saat ini telah banyak bentuk rekaman dalam berbagai media untuk mendokumentasikan Gendang Beleq, akan tetapi seringkali hal itu tidak terencana dengan baik dan belum dapat mengakomodir secara keseluruhan. Di sisi lain dokumentasi-dokumentasi yang beredar saat ini tidak terdistribusi dengan baik. Sehingga banyak informasi yang kemudian tidak tersampaikan kepada khalayak. Selain itu, begitu banyak perekaman terhadap kesenian itu tidak memiliki fokus yang jelas. Hal itu kemudian yang mendasari bahwa penelitian terhadap Gendang Beleqdalam kacamata instrumentasi dan organologimenjadi penting untuk dilakukan.

Untuk mengakomodasi keseluruhan informasi pada kesenian Gendang Beleq, tentu tidak dapat dilakukan dengan waktu yang sangat terbatas. Oleh karena itu perlu adanya batasan dalam melihat salah satu sisi kesenian ini dengan menentukan fokus penelitian. Hal yang ingin dilihat dalam penelitian ini adalah aspek Instrumentasidan Organologi kesenian Gendang Beleq pada sanggar Mertaq Mi yang berlokasi di desa Setanggor, kecamatan Praya Barat, Lombok Tengah, Nusa Tenggara Barat. Hal ini adalah sebuah upaya perekaman terhadap wujud ansambel Gendang Beleq secara utuh dan menyeluruh. Tentu saja hal ini dimaksudkan sebagai salah satu bentuk upaya untuk membuat sebuah penelitian yang berkelanjutan dengan melihat aspek material dari kesenian ini.

Kajian mendalam terhadap Gendang Beleq sejauh ini belum banyak dilakukan. Beberapa tulisan yang dapat dijumpai hanya membahas sekilas tentang keberadaan kesenian ini. Seperti halnya tulisan dalam Ensiklopedi Musik dan Tari Daerah Nusa Tenggara Barat yang hanya terbatas membahas nama-nama instrumen saja. Sumber-sumber literatur yang membahas mengenai Gendang Beleq secara khusus sampai saat ini masih belum dapat ditemukan. Hal ini sedikit menjelaskan bahwa sejauh ini belum ada upaya khusus yang dilakukan untuk mengkaji kesenian secara mendalam. Beberapa catatan tentang kesenian ini tidak jauh berbeda dengan cerita-cerita yang berkembang dalam kehidupan masyarakat Sasak. Belum tampak adanya pembuktian-pembuktian secara ilmiah yang dilakukan untuk melihat kebenaran berbagai cerita itu. Seperti halnya masyarakat meyakini bahwa kesenian ini sudah ada sejak jaman kerajaan. Akan tetapi sampai saat ini belum diketahui pasti kapan itu terjadi, dan di kerajaan mana kesenian itu muncul.Menurut Sukarman selaku ketua sanggar Mertaq Mi Setanggor, ada cerita dari masyarakat tentang awal kegunaan atau fungsi Gendang Beleq yang awalnya digunakan sebagai salah satu iringan para prajurit kerajaan saat latihan atau pada saat akan perang, hal itu cukup menjelaskan bahwa kesenian ini ada pada saat hidupnya kerajaankerajaan di pulau Lombok.

Gendang yang merupakan salah satu instrumen dalam kelompok ansambel yang dianggap masyarakat cukup ikonik. Bentuknya yang berukuran cukup besar, kemudian menjadi penanda bagi masyarakat untuk mengenali atau mengidentifikasi keberadaannya. Melalui instrumen itu masyarakat menjelaskan keberadaan kelompok ansambel Gendang Beleq. Kelompok ansambel yang tidak hanya terdiri dari instrumen Gendang, melainkan juga terdapat beberapa instrumen gong, suling, instrumen yang memiliki temol/pencon dan 
sekelompok lempeng logam (kenceng: menyerupai ceng-ceng) yang dimainkan dengan cara ditepuk.

Kesenian Gendang Beleq tersebar hampir di seluruh pulau Lombok. Menurut masyarakat pendukungnya, kesenian ini semakin surut karena berkurangnya minat masyarakat. Beberapa stigma kuno, tidak sesuai dengan zaman, dan kurang dipahaminya berbagai nilai yang tertuang pada kesenian ini menjadi beberapa alasan bahwa kesenian ini semakin diabaikan. Terlebih munculnya kesenian-kesenian baru seperti halnya kecimol, seolah menjadi salah satu tantangan bagi kesenian ini untuk terus bertahan. Munculnya kesenian baru itu menggeser keberadaan dan peran Gendang Beleq dalam ritual hidup masyarakat Sasak.Seperti halnya dalam adat nyongkolan, salah satu rangkaian adat dalam upacara pernikahan masyarakat Sasak, sebagian masyarakat lebih memilih menggunakan kecimol dari pada Gendang Beleq saat ini.

\section{Studi Organologi}

Studi organologi alat musik telah banyak dilakukan oleh para sarjana di bidang etnomusikologi. Studi organologi ini adalah upaya untuk melihat aspek kebendaan dari instrumen yang digunakan untuk memahami persoalan awal mengenai kajian Gendang Beleq. Studi instrumentasi maupun organologi digunakan untuk melihat bahwa masing-masing instrumen itu memiliki peran dan juga fungsi sebagai bagian dari ansambel, ketika meletakkannya dalam pemahaman sebagai 'alat'. Studi ini tidak kemudian dilakukan untuk mendeskripsikan alat itu sebagai alat, melainkan alat itu sebagai bagian dari seperangkat atau sekelompok ansambel.

Setelah melakukan penelitian secara langsung, ada beberapa hasil yang dicapai ketika membicarakan permasalahan terhadap objek penelitian ini, studi organologi yang dimaksud adalah tidak hanya untuk melihat instrumen fisik semata, melainkan juga unsur-unsur lainnya. Hal itu merujuk pada pandangan yang dikemukakan oleh Mantle Hood (1982:124) yang menjelaskan bahwa studi organologi ini dilakukan untuk melihat fungsi instrumen, fungsi musikal, teknik dekoratif, dan aspek sosial budayanya. Hal itu menjadi satu batasan peneliti dalam menjelaskan terkait dengan keberadaan fenomena Gendang Beleq.

Penelitian Gendang Beleq yang hanya menjadikan sanggar Mertaq Mi sebagai satu-satunya objek kajian dalam penelitian ini, tampak belum dapat mewakili keberadaan ansambel itu secara keseluruhan di Lombok, NTB. Hal itu disebabkan oleh keterbatasan data yang ditemukan di lapangan untuk merepresentasikan ansambel itu secara umum. Perlu diketahui, bahwa persebaran Gendang Beleq di Lombok ini meskipun dinilai atau dirasakan masyarakat mulai 'meredup'atau berkurang populasinya, akan tetapi di setiap wilayah kabupaten atau kota masih ada yang berupaya untuk tetap mempertahankannya. Bukan tidak mungkin jika kemudian akan muncul perbedaan baik secara bentuk fisik dari segi wujud instrumen seperti halnya penggunaan bahan dasar atau material instrumen, ataupun secara ukuran.

Sebagai salah satu wujud kebudayaan, Gendang Beleq tentu saja akan mengalami perkembangan secara dinamis sesuai dengan 'ruangnya' (baca: lingkungan). Sejalan dengan itu Steward (dalam Oekan S. Abdoellah, 2017 :75) menegaskan keberadaan budaya yang adaptif terhadap lingkungannya. Hal itu memberi sebuah gambaran bagaimana penelitian ini tidak akan dapat dapat digunakan untuk mewakili Gendang Beleq secara umum. Perbedaan 'ruang' seperti halnya karakter daerah, perbedaan geografis, ataupun lingkungan sosial di setiap wilayah diLombok sangat potensial untuk menghadirkan perbedaan pada satu konstruksi kebudayaan. Maka penelitian kali ini hanyalah upaya untuk menjelaskan fenomena Gendang Beleq dalam batasan ruang sanggar MertaqMi Setanggor, Lombok Tengah.

\section{Gendang Beleqdi Sanggar Mertaq Mi Setanggor}

Sanggar Mertaq Mi yang terdapat di desa Setanggor merupakan salah satu sanggar kesenian yang sudah cukup lama muncul dan berkembang di 
Lombok Tengah. Sanggar yang kini dipimpin oleh Sukarman ini merupakan sebuah ruang berkesenian yang muncul dan tumbuh diwariskan dari leluhurnya. Sanggar ini muncul diperkirakan pada sekitar lebih dari lima dekade silam. Hal ini didasarkan atas penuturan Sukarman (2019) yang menjelaskan bahwa sanggar itu didirikan oleh kakek buyutnya dan diwariskan kepada kakek beserta orang tuanya. Sanggar ini tidak hanya melakukan aktifitas pembelajaran dan pelestarian kesenian Gendang Beleq, melainkan juga menjadi ruang pembelajaran bagi kesenian lainnya seperti halnya Gamelan Sasak dan drama tradisi.

Gendang Beleq di sanggar Mertaq Mi saat ini masih dapat dikatakan cukup baru. Karena meski sanggar ini sudah cukup lama berdiri, akan tetapi baru pada sekitar tahun 2003 aktifitas kesenian Gendang Beleq hadir. Bakat dan musikalitas Sukarman dalam mempelajari kesenian ini yang kemudian menjadi cikal bakal hadirnya Gendang Beleq di sanggar Mertaq Mi. Awal kemunculan kesenian ini tidak bersamaan dengan hadirnya alat atau ansambel Gendang Beleq. Karena pada awal kemunculannya di sanggar ini Sukarman masih menjalankan aktifitas pembelajaran Gendang Beleq bersama dengan masyarakat di Setanggor dengan jalan meminjam gamelan di desa lainnya. Realisasi untuk memiliki seperangkat ansambel Gendang Beleq di sanggar Mertaq Mi ini baru terlaksana pada tahun 2007.

Ansambel yang sekarang terdapat di sanggar Mertaq Mi dipesan oleh Sukarman pada tahun itu dari Bali (Sukarman, 2019). Hal itu dikarenakan sulitnya menemukan pengrajin alat-alat kesenian terutama pembuat perangkat Gendang Beleq. Tetapi tidak seluruhnya instrumen yang digunakan dipesan atau dibuat di Bali, melainkan terdapat beberapa instrumen dalam perangkat itu yang dibuat oleh Sukarman sendiri yaitu instrumen suling dan rangkaian pengeras suara untuk instrumen tersebut. Selain suling, instrumen Gendang juga dibuat di Lombok olehnya sendiri.

Perangkat Gendang Beleq yang muncul pada tahun 2007 itu masih dipertahankan keberadaannya hingga sekarang. Tidak ada perubahan signifikan yang dihadirkan terhadap wujud ataupun bentuk dari instrumen yang ada. Perubahan-perubahan yang dihadirkan sejauh ini hanya sebatas perawatan terhadap instrumen yang ada, selain juga perbaikan terhadap suatu kerusakan yang terjadi. Menurut Sukarman belum ada kerusakan yang berarti terkait dengan keberadaan ansambel itu. Kerusakan yang sering terjadi hanya sebatas pada penggunaan alat tabuh(pemukul) semata.

\section{Pengelompokan Instrumen}

Instrumen musik secara umum berdasar fungsinya dalam ansambel dibagi menjadi tiga macam atau jenis instrumen, diantaranya adalah instrumen melodis, harmonis, dan ritmis. Berdasar pada pandangan Purwani (dalam Dwi Yatminah, 2018:36) menjelaskan bahwa instrumen melodis merupakan perangkat instrumen yang digunakan untuk memainkan unsur melodis atau melodi lagu pada sebuah sajian musik. Selanjutnya ia menjelaskan bahwa instrumen harmonis ini digunakan untuk mengiringi sajian melodi lagu, sedangkan instrumen ritmis diidentifikasi sebagai instrumen yang tidak bernada dan merupakan instrumen atau alat untuk membangun ritme atau irama.

Berdasarkan pada fungsi masing-masing instrumen dalam ansambel dapat diidentifikasi bahwa pada ansambel Gendang Beleq hanya terdapat dua kelompok instrumen saja, yaitu instrumen melodis dan ritmis. Identifikasi ini didasarkan pada keberadaan instrumen suling dan Reyong sebagai kelompok instrumen melodis. Kedua instrumen itu dalam sajian Gendang Beleq menghadirkan atau menyajikan pola melodi yang sama. Meskipun kedua instrumen itu memiliki perbedaan karakter bunyi, akan tetapi nada atau melodi lagu yang disajikan lebih bersifat unison (persamaan bunyi). Hal itu menjelaskan bahwa pola permainan atau sajian dari suling bukan merupakan bentuk íringan bagi sajian Reyong ataupun sebaliknya. Kelompok instrumen lain yang terdapat dalam Gendang Beleq merupakan kelompok dari instrumen ritmis. Kelompok instrumen ritmis pada ansambel Gendang 
Beleq terdiri dari instrumen Gendang, Gong Beleq, Petuq, Rincik, Kenceng, dan Kempur.

\section{Instrumen Gendang}

Gendang dalam ansambel Gendang Beleq merupakan instrumen yang dianggap cukup ikonik yang selanjutnya menjadi penanda (identitas) dari kesenian ini. Bentuk dan ukurannya yang dianggap tak lazim itu menjadi salah satu cara untuk mengidentifikasi kekhasan dari perangkat ansambel ini. Penyebutan istilah Gendang Beleq ini pada dasarnya dilatar belakangi oleh keberadaan instrumen gendangnya. Sri Yaningsih, dkk. (1988:103) menjelaskan bahwa ansambel ini disebut Gendang Beleq karena gendang ini ukurannya besar, dibanding dengan ukuran gendang pada umumnya. Lebih lanjut ia juga menjelaskan bahwa istilah gendang ini disamakan dengan pemahaman umum mengenai gendang, sedangkan beleq memiliki pengertian besar (ukurannya).

Gendang berdasar sumber bunyinya dikelompokkan sebagai jenis instrumen membranophone. Di dalam menghasilkan bunyi pada permainannya instrumen ini memanfaatkan membran sebagai sumber bunyi utamanya. Instrumen gendang umumnya dibuat menggunakan kayu tap, yaitu sejenis kayu bergetah yang memiliki tipikal bahan ringan tetapi kuat. Ada juga yang menggunakan kayu randu, boroq, maupun nitaq. Instrumen gendangberbentuk tabung dengan membran yang terpasang di kedua sisinya disebut masyarakat sebagai rampeng. Rampeng yang menjadi sumber bunyi utamanya terbuat atau berbahan dasar lendong sampi atau kulit sapi. Untuk menghasilkan bunyi, gendang dipukul dengan menggunakan pemantok atau pemukul. Pemukul gendang iniberbentuk stik dengan terdapat bulatan atau "pentol" pada ujungnya.

Instrumen Gendang secara umum memiliki 4 bagian utama dalam struktur bentuknya. Bagian pertama adalah pertama adalah penampang gendang atau rampeng atau membrane. Bagian kedua adalah bantang atau tubuh instrumen yang berbentuk tabung. Bantang dalam instrumen
Gendang memiliki fungsi sebagai ruang resonator bunyi. Bagian ketiga adalah jangat adalah tali pengikat yang membujur dan menghubungkan kedua sisi rampeng. Jangat dalam instrumen ini terbuat dari lulang atau kulit. Keberadaan jangat ini digunakan untuk mengatur tingkat ketegangan kedua rampeng, di mana hal ini akan berimplikasi pada tinggi rendahnya suara yang dihasilkan oleh gendang. Bagian keempat adalah wangkis, yaitu tali penguat yang melingkari rampeng yang berfungsi sebagai penguat dan berbahan dasar kulit.

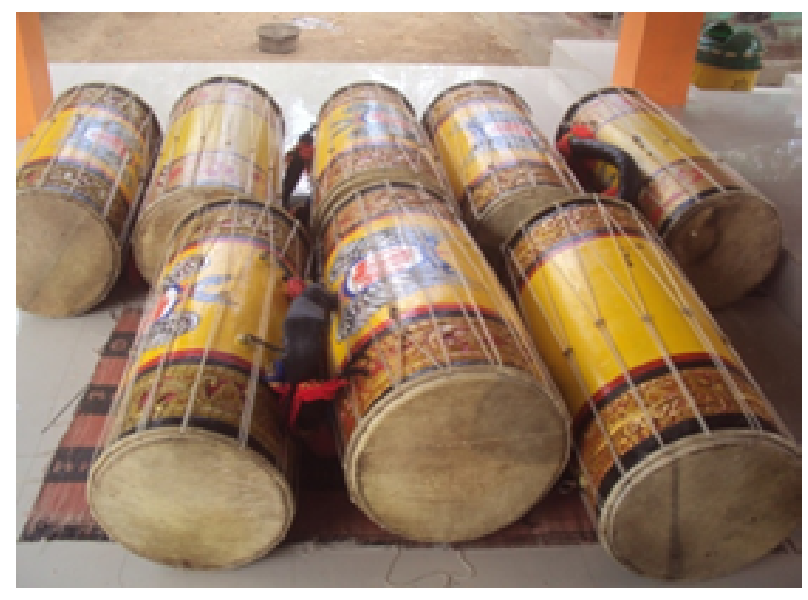

Gambar 1. Instrumen Gendang di Sanggar Mertaq Mi Setanggor

(Foto: Lalu Dwi Satria Ardiansyah, 2019)

Ditinjau dari segi bahan yang digunakan untuk membuat instrumen gendang, Sanggar Mertaq MiDesa Setanggor mengunakan bahan dari pohon randu atau pohon kapas. Pohon randu dipilih sebagai bahan pembuatan gendang karena selain kayu tidak terlalu berat, serta kelebihan lainnya adalah kualitas yang dihasilkan nyaring. Sebagian gendang yang terdapat di sanggar Mertaq Mi ada juga yang memakai kayu lekong, kayu boroq, dan kayu nitaq. Pemilihan bahan kayu tentunya menjadi perhatian utama dalam hal kualitas bunyi yang nantinya akan dihasilkan.

Pemilihan bahan dalam pembuatan instrumen Gendang selain dilakukan dengan memperhatikan kualitas bahan, juga dilakukan berdasar atas ketersediaan bahan. Bahan kayu yang digunakan Sukarman itu dipilih karena mudah 
didapatkan di Lombok. Memperhitungkan lingkar kayu yang memiliki diameter cukup besar untuk dapat digunakan membuat instrumen ini tentu saja tidak dapat dilakukan dengan sembarang memilih jenis pohon. Pemilihan bahan jenis lain mungkin dapat dilakukan, seperti halnya dengan menggunakan kayu dari pohon nangka yang dikenal dan diketahui banyak kalangan dapat menghasilkan bunyi yang cukup baik jika digunakan untuk membuat instrumen sejenis gendang. Akan tetapi keberadaan pohon nangka dengan diameter yang cukup besar tentu akan sulit untuk didapatkan di Lombok. Selain sulit didapat, kemungkinan lainnya adalah jenis masa dari bahan kayu tersebut yang cenderung lebih berat. Hal ini menjelaskan bagaimana lingkungan atau ekologi dapat berpengaruh terhadap bagaimana suatu budaya terbentuk.

Ketika berbicara gendang secara instrumentasi, maka secara umum gendang memiliki fungsi sebagai pemurba irama. Artinya pola ritmik yang dihasilkan gendang mampu menjadikan sebuah gending itu menjadi cepat ataupun lambat. Hal yang lainnya adalah gendang mampu menjadi tanda bahwa gending itu akan berubah pola serta menjadi penegas dari pukulan kenceng (ceng-ceng) dalam hal pola ritmiknya. Gendang secara khusus dibagi menjadi dua bagian yang berbeda mengenai timbre atau karakter suara. Pertama adalah gendangmame (laki-laki) dan yang kedua adalah gendangnine (perempuan) yang memiliki perbedaan karakter antara keduanya. Gendangmame memiliki karakteristik suara yang lebih tinggi (dag), begitupun sebaliknya jika gendangnine memiliki karakter suara yang rendah (dug).

Sumber bunyi utama instrumen gendang, dihasilkan olehmembran berupa kulit. Jenis kulit yang digunakan oleh Sanggar Mertaq Mi sebagai membrane gendang adalah kulit kambing. Pemilihan kulit kambing juga berdasarkan usia hewan, pengolahan kulit, dan sebagainya. Pemilihan jenis membran kulit kambing menjadi pilihan Sanggar Mertaq Mi karena harga murah, gampang dicari, serta mengolahnya tidak terlalu sulit. Berbeda pula jika kulit yang dipilih seperti sapi ataupun kerbau, tentu berbeda harga dan cara pengolahannya. Setiap kulit hewan tentu memiliki ciri khas ketika dipadankan dengan bahan lainnya.

Teknik memukul gendang dalam permainan Gendang Beleqakan menghasilkan bermacam jenis bunyi. Bunyi dung atau duk merupakan bunyi yang dihasilkan dari memukul salah satu rampeng dengan menggunakan pemantok(alat pukul). Dag dalam Gendang Beleq merupakan simbolisasi bunyi pada gendang mame atau lanang, sedang dugadalah simbol dari bunyi pada gendangnine atau wadon. Untuk menghasilkan bunyi dagatau dugadalah dengan cara mengayunkan pemantok pada salah satu rampengnya. Benturan antara pemantok dan rampeng yang disertai gaung panjang itu yang ditengarai sebagai bunyi dagatau dug. Bunyi lainnya dihasilkan dengan memukul salah satu rampeng dengan telapak tangan dengan tetap menahan tangan melekat pada rampeng sehingga tidak timbul gaung baik pada gendangmama ataupun gendangnine yang itu disimbolkan sebagai bunyi plak.

Pola yang antara kedua instrumen ini juga memiliki perbedaan, artinya ketika gending dimainkan keduanya saling melakukan teknik imbal. Entah dari segi pola tabuhan ketika tangan kanan memakai pemukul serta pola imbal saat melakukan pola plak di tangan kiri. Selama melakukan observasi serta pengukuran secara langsung maka didapatkan hasil berupa panjang gendang, luas lingkaran, diameter, ketebalan kayu, serta ramping gendang (lingkaran yang terbuat dari rotan dan dilapisi kulit, sebagai pengencang membrane kulit).

\section{Instrumen Reyong}

Reyong merupakan instrumen jenis ideophone yang terbuat dari logam berdasar pada sumber bunyinya. Tubuh instrumen yang terbuat dari logam ini merupakan sumber bunyi dalam penyajian atau permainannya. Instrumen ini dibuat dariberbagai jenis logam seperti halnya besi, kuningan, atau perunggu. Penggunaan bahan itu tergantung dari kebutuhan seniman terhadap bunyi yang dihasilkan. Karena masing-masing jenis logam yang digunakan pastinya memilki tingkat kerapatan yang mana hal itu akan menjadikan setiap bahan akan dapat 
menghadirkan timbre yang berbeda pula. Perbedaan jenis bahan yang digunakan ini salah satu yang paling tampak adalah muncul dan tidaknya dengung setiap kali instrumen itu dimainkan. Ada atau tidaknya dengung (gaung) yang dimaksud akan tampak jelas jika membandingkan dua instrumen atau lebih yang serupa akan tetapi memiliki bahan dasar yang berbeda. Suatu contoh bahwa instrumen dengan bahan perunggu akan cenderung menghasilkan bunyi yang lebih panjang atau lama jika dibanding dengan instrumen berbahan dasar besi.

Instrumen Reyong yang terdapat di sanggar Mertaq Mi terbuat dari bahan perunggu. Perunggu merupakan campuran tembaga dengan unsur kimia lain, biasanya dengan timah, walaupun bisa juga dengan unsur-unsur lain seperti fosfor, mangan, alumunium, atau silikon. Perunggu bersifat keras dan cocok digunakan untuk pembuatan gamelan.

Instrumen Reyong dalam Gendang Beleq merupakan instrumen yang penting sebagai penguat unsur melodis. Ketika para penabuh memainkan Reyong, maka secara auditif akan diketahui mengenai alur gending yang sesuai dengan bentuk dan strukturnya. Serupa dengan Gendang Beleq, Reyong dimainkan dengan teknik atau cara imbal antara penyaji satu dengan lainnya.

Secara fisik, instrumen ini secara keseluruhan terdapat dua bagian penting. Bagian pertama berbentuk lingkaran dan memiliki temol (pencon) sebagai sumber utama bunyi. Untuk menghasilkan bunyi dalam penyajian instrumen ini adalah dengan mengayunkan alat pemukul pada temol. Bagian lain dari instrumen reyong adalah tubuh atau badan instrumen. Badan instrumen berfungsi sebagai resonator, yaitu ruang rambat bunyi yang dihasilkan dari temol. Tidak ada pembatas khusus yang dibuat dari keduanya. Bahan reyong yang terdapat di Sanggar MertaqMi terbuat dari perunggu, hal itu dipilih karena karakter bunyi dari perunggu dinilai lebih baik oleh Sukarman dan tentunya suara yang dihasilkan akan lebih nyaring dibandingkan bahan besi.

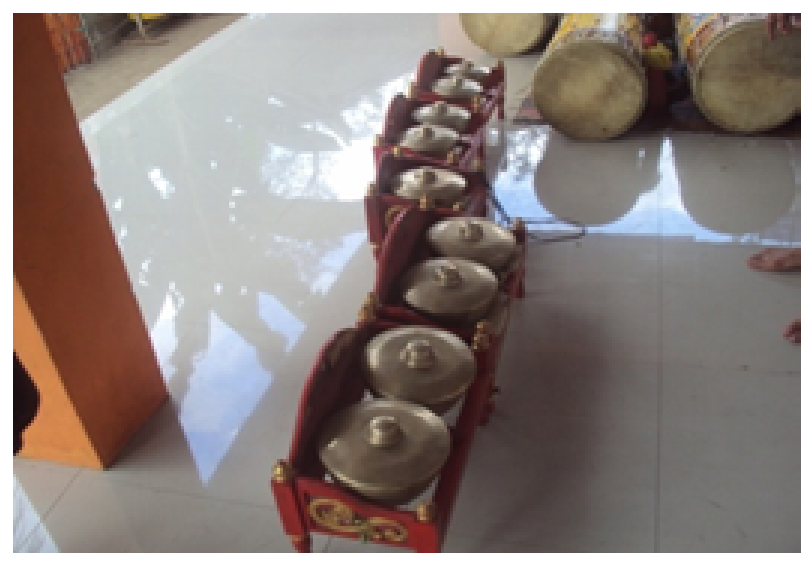

Gambar 2. Instrumen Reyong di Sanggar Mertaq Mi Setanggor

(Foto: Lalu Dwi Satria Ardiansyah, 2019)

Bale Reyong digunakan untuk membawa instrumen saat dimainkan atau disajikan. Bale reyong adalah tempat yang terbuat dari bahan kayu berbentuk tabung persegi. Di dalam penyajian Gendang Beleq setiap penyaji reyong hanya membawa satu bale reyong yang terdapat dua instrumen reyong dengan nada berbeda. Biasanya pada sajian Gendang Beleq hanya menghadirkan sepasang pemain reyong atau hanya terdiri dari empat instrumen yang digunakan, karena masingmasing penyaji membawa dua instrumen reyong.

Perangkat reyong yang dimiliki Sanggar Mertaq Mi merupakan pengembangan dari nada nada yang terdapat di gamelan Sasak. Jadi total jumlah reyong yang dipakai ketika sanggar Mertaq Mi pentas adalah 9 (sembilan)reyong. Alasan utama Sukarman, bahwa dengan memakai reyong berjumlah sembilan maka untuk memainkan gendinggending kreasi yang sama dengan bilah gamelan akan mudah untuk menyesuaikan. Secara auditifjuga kesannya lebih meriah. Instrumen reyong di bagian bawah terdapat lubang untuk pengikat supaya ketika pentas tidak sampai terjatuh. Tali yang dipakai untuk mengikat adalah jenis tali berbahan tasi. Sedangkan untuk bale reyong (tempat reyong) mengunakan bahan dari kayu. 


\section{Instrumen Gong Beleq}

Gong merupakan sebuah alat musik pukul yang tersebar di beberapa pulau Indonesia. Sama halnya dengan penyebutan di beberapa daerah bahwa instrumen ini dinamakan gong adalah hasil dari onomatopoe atau nama yang disematkan yang sesuai dengan sumber bunyinya. Dalam perangkat Gendang Beleq, gong menjadi instrumen yang paling penting, karena ketika gending dimainkan pada saat awal dan akhir, instrumen gong menjadipenentu rasa dari keseluruhan komposisi yang dimainkan. Ada yang beranggapan bahwa jika gong tidak ditabuh maka ada cita rasa musikal yang hilang. Meskipun tidak akan muncul perubahan yang signifikan secara musikal ketika instrumen ini tidak ditabuh, akan tetapi akan merubah citra estetik yang dihadirkan dalam keseluruhan sajian.

Serupa dengan instrumen reyong, instrumen ini berdasar sumber bunyinya termasuk dalam kategori instrumen ideophone. Secara struktur instrumen ini dibagi menjadi dua bagian ruang. Temol pada bagian atas yang berbentuk benjolan merupakan bagian utama instrumen ini dalam menghasilkan bunyi. Di mana dalam membunyikan instrumen ini pelaku menggunakan sebuah pemantok yang terbuat dari kayu dan dililit dengan bahan yang lentur seperti halnya karet yang dilapisi kain. Bagian lainnya adalah tubuh instrumen yang berbentuk tabung pipih yang berfungsi sebagai resonator. Umumnya gong ini banyak dijumpai dibuat dengan menggunakan bahan besi. Penggunaan bahan besi biasanya dilakukan dengan pertimbangan ketersediaan bahan, pengrajin, dan juga biaya pembuatan.

Di mana di Lombok masih sangat sulit menemukan pengrajin instrumen musik yang membuat instrumen musik dengan berbahan dasar perunggu atau kuningan. Selain itu biaya bahan ataupun pengerjaan instrumen dengan bahan perunggu jauh lebih mahal dibanding dengan instrumen berbahan dasar besi.

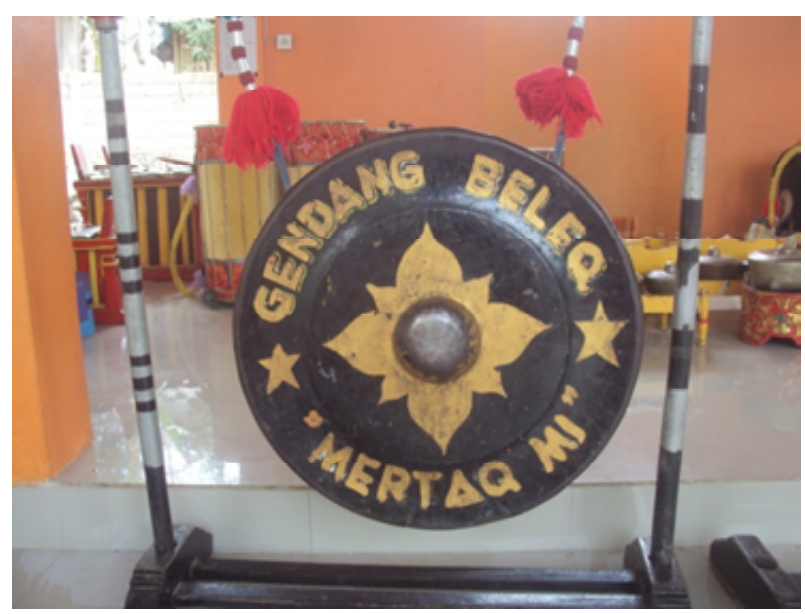

Gambar 3. Instrumen Gong Beleq di Sanggar Mertaq Mi Setanggor

(Foto: Lalu Dwi Satria Ardiansyah, 2019)

Istilah gong beleq sendiri berarti 'gong besar', karena kata beleq dalam kebudayaan masyarakat Sasak memiliki arti 'besar'. Bahan yang digunakan dalam pembuatan gong bisa dari perunggu maupun besi. Dilihat dari segi kualitas, memang bahan gong yang terbuat dari perunggu lebih nyaring, kuat, serta memiliki sustain bunyi yang menggelegar. Dari segi harga juga relatif mahal. Sedangkan besi, dari segi harga murah, lebih enteng, hanya saja karakter suara yang dihasilkan kurang mengelegar.

Gong Beleq yang terdapat di sanggar Mertaq Mi terbuat dari bahan besi. Hal itu dipilih karena beberapa faktor di antaranya adalah harga dan penggunaan instrumen dalam penyajian. Faktor harga jelas gong dengan bahan besijauh lebih murah jika dibanding dengan yang berbahan kuningan ataupun perunggu. Selain itu untuk kebutuhan pertunjukan Gendang Beleq yang sarat dengan mobilitas (untuk kebutuhan arak-arakan), gong berbahan dasar besi dinilai lebih ringan untuk dibawa jika dibanding dengan gong yang terbuat dari kuningan atau perunggu.

\section{Oncer atau Petuq}

Instrumen oncer ataupetuq merupakan salah satu alat musik yang sangat penting dalam menjaga tempo. Seorang pemain petuq dalam Gendang 
Beleq harus memiliki hafalan yang bagus dalam hal penguasaan gending. Gending menjadi cepat atau lambat tergantung darikomunikasi pemain petuq dengan beberapa pemain lainnya. Selain berfungsi sebagai penjaga tempo, pemain ketuk juga sering melakukan variasi gerakan saat bermain gamelan secara kolektif. Gerakan-gerakan yang dilakukan supaya para pemain gamelan yang lain turut semangat serta mendengarkan aba-aba dari petuq.

Petuq secara organologis memiliki persamaan bentuk dengan reyong, hanya saja diameternya lebih besar dan bunyi yang dihasilkan oleh instrumen cenderung rendah dibandingkan reyong. Terkadang pemain petuq menutup bagian tubuh instrumen, serta membukanya. Hal tersebut supaya terjadi pola yang variatif dalam menafsirkan tempo maupun karakteristik bunyi. Berdasar sumber bunyinya instrumen petuqtermasuk dalam jenis instrumen ideophone, serupa dengan instrumen reyong ataupun gong. Sekilas instrumen ini tampak serupa dengan bentuk instrumen reyong. Petuq terdiri dari dua bagian yang sama dengan reyong, yaitu temol sebagai sumber bunyi dan tubuh instrumen yang digunakan sebagai media atau ruang rambat bunyi.

Petuq yang dimilikioleh sanggar Mertaq Mi berbahan dasar perunggu. Penggunaan bahan perunggu ini dilakukan atas dasar kebutuhan karakter dan warna suara dalam sajian Gendang Beleq. Material perunggu yang cenderung lebih padat jika dibanding dengan besi dinilai dapat menghasilkan kualitas suara yang bagus. Meski penggunaan perunggu sebagai bahan dasar dinilai menjadikan instrumen ini lebih berat dibanding instrumen dengan material besi, akan tetapi bentuk dan ukuran instrumen yang tidak terlalu besar menjadikan beban atau berat instrumen tidak menjadi persoalan dalam penyajiannya.

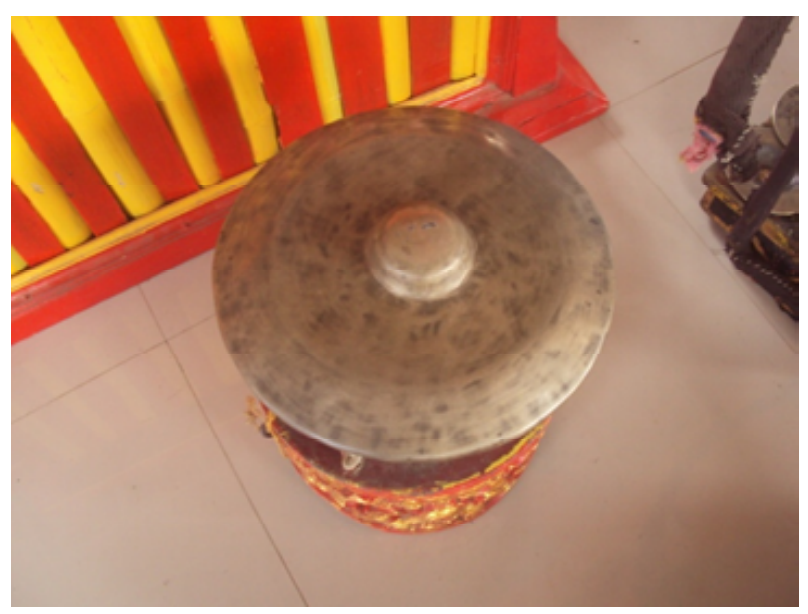

Gambar 4. Instrumen Petuq di Sanggar Mertaq Mi Setanggor

(Foto: Lalu Dwi Satria Ardiansyah, 2019)

Di dalam penyajiannya dalam satu kelompok sajian Gendang Beleqhanya terdapat satu orang yang berperan memainkan instrumen ini. Untuk memainkannya biasanya penyaji tidak memerlukan adanya bale petuq atau tempat khusus yang digunakan untuk membawa petuq. Penyaji hanya memanfaatkan kedua tangannya untuk memainkan instrumen ini, di mana salah satu tangannya digunakan untuk memegang instrumen, sedang tangan yang lain digunakan untuk membawa alat tabuh atau pemukul. Alat tabuh atau pemukul untuk instrumen ini sama dengan alat tabuh yang digunakan untuk membunyikan reyong. Tabuh yang digunakan terbuat dari kayu dan pada bagian ujunganya terdapat gulungan atau lilitan tali yang tampak lentur tetapi cukup keras.

\section{Rincik}

Instrumen rincik merupakan instrumen tambahan yang berfungsi sebagai tempo sekaligus pengisi celah-celah gending yang kosong apabila kenceng tidak dimainkan. Rincik memiliki suara yang khas hampir sama fungsinya dengan instrumen marakas yang sering digunakan sebagai pengisi saat kelompok musik memainkan ansambel akustik. Seorang pemain rincik, harus paham tentang gending yang dimainkan, karena instrumen ini tidak lepas dari 
petuq. Keduanya memiliki fungsi yang hampir sama hanya saja permainan rincik harus seimbang mengenai penguasaan volume, dinamika, sera ritmis ketika berhadapan dengan gending. Instrumen rincik yang dimiliki sanggar Mertaq Mi berbahan dasar perunggu.

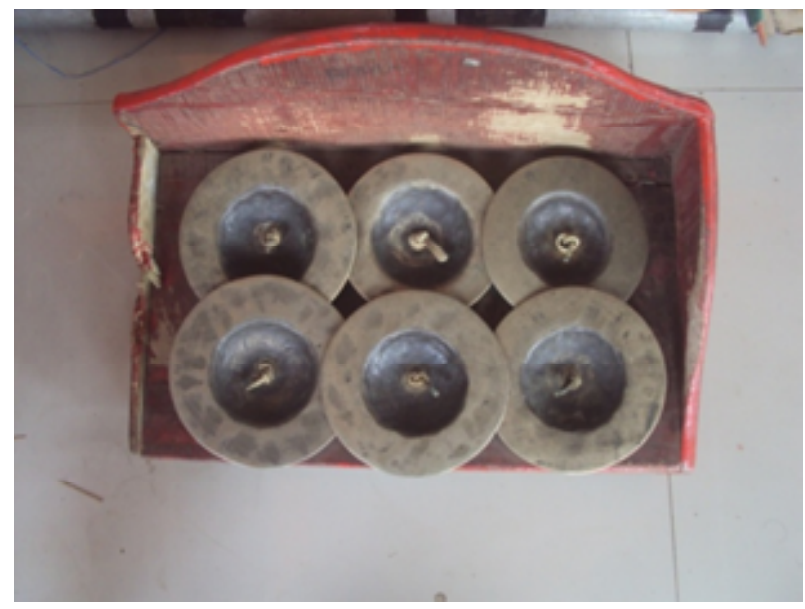

Gambar 5. Instrumen Rincik di Sanggar Mertaq Mi Setanggor

(Foto: Lalu Dwi Satria Ardiansyah, 2019)

\section{Kenceng}

Selanjutnya adalah instrumen kenceng. Instrumen ini memiliki peranan yang sangat penting karena pemain diharuskan memiliki penguasaan pola ritmik yang beragam. Terkadang pola yang dimainkan antara pemain kenceng satu dengan yang lainnnya berbeda-beda pola. Hal inilah yang harus dikuasai bahwa ketika bermain kenceng, telinga kita harus fokus terhadap pola yang kita mainkan. Kenceng juga memiliki peranan sebagai membangkitkan atmosfir pertunjukan. Semakin banyak instrumen kenceng yang dipakai maka akan semakin ramai suara dan gending lebih berkarakter. Pola permainan kenceng terkadang mengikuti ritmik gendang dan juga pola kenceng membuat pola yang berbeda dengan gendang yang disesuikan dengan gending yang dimainkan.

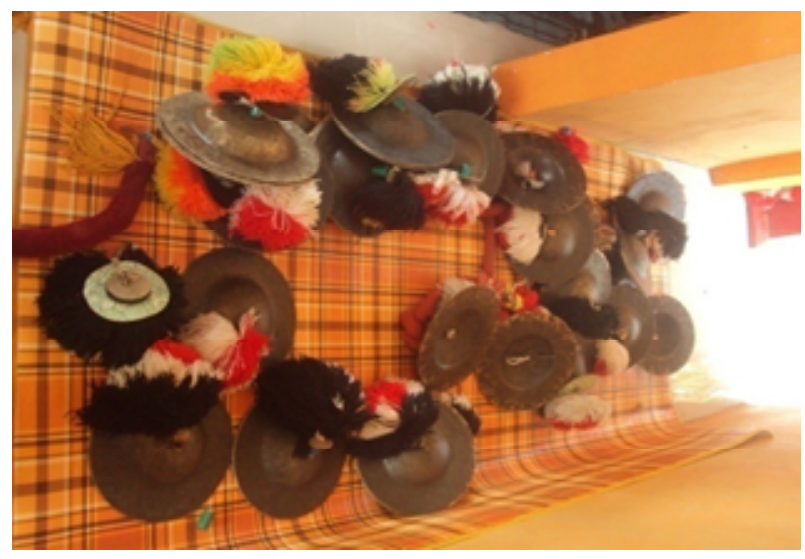

Gambar 6. Instrumen Kenceng di Sanggar Mertaq Mi Setanggor

(Foto: Lalu Dwi Satria Ardiansyah, 2019)

\section{Daftar Ukuran Ansambel Gendang BeleqMertaq Mi Setanggor}

Berdasarkan pembahasan diatas mengenai instrumentasi yang kaitannya dengan fungsi instrumen, bahan instrumen serta beberapa paparan yang melekat terhadap karakteristik khususnya Gendang Beleq Sanggar Mertaq Mi Setanggor, maka penulis ingin memaparkan tentang daftar ukuran masingmasing instrumen yang nantinya perbedaan ukuran ini menjadi karakteristik masing-masing Gendang Beleq yang tersebar di NTB. Berikut daftar ukuran ansambel Gendang Beleq sanggar Mertaq Mi Setanggor:

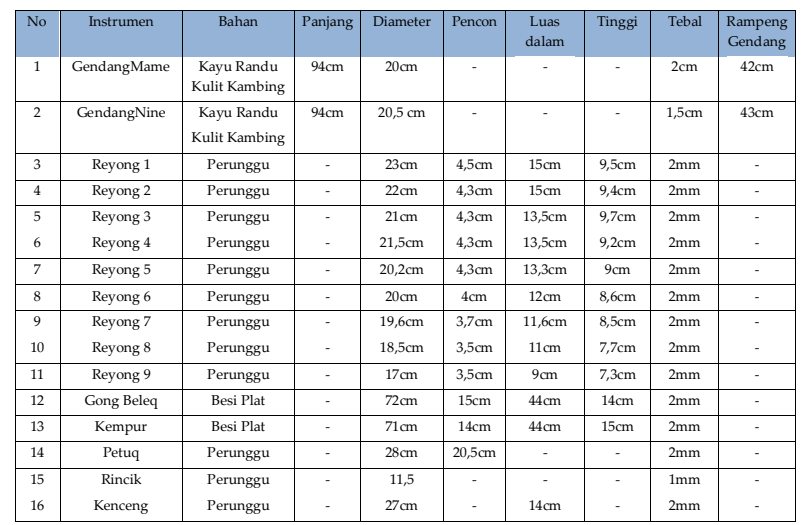

Tabel 1. Daftar ukuran ansambel Gendang Beleq 


\section{Penjelasan Daftar Ukuran}

Jika mengamati ukuran dari gendang mame dan nine dapat kita lihat perbedaan secara organologis tentang diameter gendang, tebal kayu gendang, serta ramping gendang. Perbedaan ini menentukan karakteristik bunyi yang dihasilkan oleh kedua gendang. Disamping itu, perbedaan membran kulit juga sangat mempengaruhi bunyi. Pemilihan kulit seperti sapi, kambing, kerbau dan sebagainya tentu menjadi pertimbangan tersendiri bagi pelaku instrumen gendang.

Selanjutnya ketebalan kayu juga sangat mempengaruhi bunyi yang dihasilkan oleh instrumen gendang. Semakin tebal kayu maka suara yang dihasilkan memiliki gema yang sedikit, hal tersebut jika kita hadapkan dengan persoalan Gendang Beleq maka memilih kayu dengan tebal yang melebihi secara organologis maka akan menyulitkan para pemain gendang dalam hal pelarasan bunyi sekaligus kenyamanan dalam hal pentas karena semakin tebal kayu maka semakin berat. Disamping itu, masingmasing pelaku gendang memiliki ciri khas dalam hal pelarasan gendang, hal ini dikarenakan cita rasa estetis dalam menentukan karakter yang diinginkan.

Pemilihan jenis kayu randu tentunya disesuaikan dengan berat kayu, karena yang kita ketahui bahwa kesenian Gendang Beleq secara pertunjukannya lebih menekankan pada prosesi arak-arakan. Entah acara perkawinan, acara dinas, serta yang terkait dengan seremonial kebudayaan di Lombok.

Selanjutnya kita lihat bahwa ukuran masingmasing reyong satu sampai sembilan memiliki perbedaan ukuran diameter, temol/pencon, luas dalam, tinggi walaupunmemiliki ketebalan dan bahan yang sama. Bahan perunggu menjadi salah satu bahan yang paling digemari oleh kalangan seniman gamelan karena memiliki kualitas bahan yang bagus dan menghasilkan suara yang nyaring. Begitu pula dengan masing-masing personal pembuat gamelan tentu memiliki pengalaman serta pemahaman tersendiri dalam membuat gamelan.

Seorang pande gamelan atau pembuat gamelan tentu sangat mempertimbangkan bahan gamelan, proses pembuatan, hingga tahap pelarasannya. Setiap pembuat gamelan memiliki racikan yang berbeda-beda dalam hal menentukan campuran. Tidak hanya itu, tahapan pemanasan bahan hingga akhirnya menjadi bentuk yang melewati proses tempaan tentu dikerjakan secara kolektif guna memperoleh hasil yang diinginkan.

Saat reyong ditempa, seorang pande gong dari desa Tihingan Klungkung Bali pernah berkata kepada penulis bahwa proses penempaan harus cepat diputar dan ditempa supaya rata ketebalannya. Ada yang memegang tang besi, ada yang menempa bagian dalam, ada yang khusus untuk memanaskan gong dan mencelupkannya kembali di air dan sebagainya. Tidak cukup sampai disana saja bahwa dalam proses tersebut seseorang yang ditunjukan untuk pelarasan bunyi mengetahui jika proses pembakaran, penempaan, pencelupan harus memepertimbangkan persoalan rasa pada saat melakukan proses. Tidak sekedar menempa tapi harus memiliki pengetahuan tentang bagian-bagian mana saja yang harus ditempa serta ketebalan harus rata.

Setelah melakukan proses penempaan hingga menjadi bentuk reyong, maka ditentukan pelarasan yang sesuai dengan karakter pesanan. Umumnya para pemesan reyong, gong, kempur, hingga gangsa mereka memberikan contoh petuding (nada yang digunakan sebagai acuan). Nada tersebut menjadi karakter keseluruhan cita rasa gamelan. Terkadang setiap gamelan memiliki karakter yang agung, keras, lembut tergantung dari tuning system (pelarasan), pemilihan bahan baku, jarak lubang resonator dengan instrumen, pelawah atau rancakan, serta aspek-aspek lainnya.

Mengamati perbedaan ukuran dari kesembilan reyong yang terdapat di sanggar Mertaq Mi maka pemakaian bahan perunggu sebagai instrumen melodis tentu sangat bagus untuk menghasilkan bunyi yang diinginkan. Perunggu memiliki karakter yang lebih nyaring dibandingkan besi serta jika dimainkan pada lokasi outdoorbahan ini sangat cocok. Besar kecilnya bentuk reyong juga menentukan karakteristik nada yang berbeda-beda. Jika kita telusuri, bahwa reyong satu sampai 
sembilan memiliki ukuran yang berurutan. Reyong satu yang paling besar dan reyong sembilan yang paling kecil. Perbedaan diameter, luas dalam, pencon, dan tinggi menentukan estetika secara bentuk instrumen, resonator bunyi, panjang pendeknya sustain gamelan, pelarasan, serta cita rasa musikal ketika dimainkan secara bersamaan.

Selanjutnya adalah instrumen petuq/oncer, kempur dan gong. Ketiga instrumen ini juga menjadi nyawa dalam hal menentukan tempo lagu (petuq), kempur sebagai pengisi hitungan frasa tanya dalam lagu sekaligus gong yang menjadi frasa penutup dalam setiap gending. Jika di Jawa ada padhangulian dalam Gamelan Ageng yang digunakan sebagai patokan frase tanya maupun jawab pada setiap gending. Bahan instrumen petuq di sanggar Mertaq Mi Setanggor terbuat dari bahan perunggu dan hal ini sangat cocok untuk kebutuhan pentas di outdoor karena petuq memiliki fungsi sebagai pemegang tempo dalam sebuah gending. Jika seorang pemain petuq bermain cepat maka semua instrumen ikut cepat, begitupun sebaliknya.

Berbeda bahan dengan kempur dan gong yang dimiliki oleh sanggar Mertaq Mi Setanggor. Bahan yang digunakan adalah besi. Penulis bertanya kepada ketua sanggar, apa alasan terkuat memilih besi pada instrumen kempur dan gong? Sukarman menjawab bahwa sebetulnya dia menginginkan semua instrumen memakai bahan perunggu namun karena sanggar masih butuh tambahan dana untuk membeli gong perunggu maka para personil diwajibkan untuk menabung untuk membeli gong dan kempur perunggu. Sukarman juga memaparkan bahwa kelebihan dan kekurangan jika memakai gong berbahan besi ialah harga relatif murah dan ringan saat dibawa arak-arakan. Sedangkan kekurangannya adalah tidak memiliki bunyi yang nyaring seperti instrument berbahan perunggu lainnya. Karena perunggu memiliki karakteristik yang lebih unggul dalam hal bunyi maupun bahan dasar tetapi harga yang lebih mahal.

Perbedaan ukuran petuq dibandingkan reyong jelas memberikan kesan yang berbeda dalam pelarasannya. Walaupun memiliki bentuk yang sama tetapi dari segi fungsi instrumentasi kedunya memiliki peran yang berbeda dalam hal pola tabuhan. Petuq sebagai pengendali tempo sedangkan reyong yang membuat pola melodis dengan memainkan teknik imbal dalam reyong polos dan reyong sangsih. Sedangkan gong dan kempur juga memiliki ukuran yang berbeda dalam hal diameter, lebar pencon, dan tinggi. Perbedaan ini juga berlaku terhadap fungsi kedua instrumen dalam seni Gendang Beleq. Tidak seperti instrumen lainnya yang terlihat atraktif ketika dipresentasikan, namun kehadiran kempur dan gong merupakan instrumen yang berfungsi untuk memantapkan gending. Ketika frasa tanya dan jawab dalam alur melodi dimainkan tanpa ada bunyi kempur dan gong maka nuansa lagu tidak terasa hidup. Serasa ada yang kurang dalam gending tersebut dan kesannya tidak mantap jika kempur dan gong tidak ditabuh.

Instrumen terakhir adalah rinciq dan kenceng. Instrumen ini memiliki persamaan bentuk namun berbeda cara memainkannya. Secara organologis, rinciq lebih kecil dan karakter bunyi yang dihasilkan lebih tinggi dalam hal frekwensi dikarenakan fungsi instrumen ini sebagai pengisi dari tempo petuq (pembuat jalan gending). Sedangkan kenceng memiliki diameter yang lebih besar dan menjadi pemegang ritmik yang paling dominan selain gendang. Kenceng dalam permainan gending Gendang Beleq menjadi penghias pola ritmik. Motifmotif pukulan kenceng juga bervariasi dari pukulan polos (pukulan dasar) hingga sangsih (pukulan imbal).

\section{Penutup}

Kajian Instrumentasi dan Organologi merupakan wilayah yang sangat jarang disentuh, hal ini tentunya menjadi stimulus bagi penulis agar terus menggali tentang apa saja yang terdapat dalam obyek material yaitu GendangBeleqMertaqMi. Cara pandang riset etnomusikologi dipakai sebagai pondasi awal karena melalui riset ini, penulis dihadapkan beberapa persoalan terkait tekstual yang berhubungan dengan alat musik maupun musik secara kontekstual yang kaitannya dengan kebudayaan masyarakat Sasak. Gendang Beleq 
Mertaq Mi digunakan sebagai obyek material, tentu menjadi bahan yang menarik untuk digali sekaligus menjadi penelitian lanjutan ditahapan berikutnya.

Dinamakan gendangbeleq atau gendangbesar tentu kehadiran kesenian ini sangat dipertimbangkan dari segi akustika instrumen serta pemahaman pelaku seni terhadap akustika ruang. Artinya secara tidak sadar, proses yang dilakukan para pemain gendangbeleq erat kaitannya dengan pengenalan ilmu organologi sekaligus mereka juga diberikan mengenai pemahan ruang pertunjukan yang tepat sesuai dengan karakteristik instrumen.Dengan tahapan pembahasan mengenai instrumentasi dan organologi yang mengambil satu sampel kelompok Gendang Beleq, setidaknya menjadi stimulus bagi penulis lain maupun kelompok lainnya untuk menjaga kekhasan yang telah dimiliki sekaligus upaya mempertahankan gendang beleq bagi masyarakat Sasak agar lebih mengenal budayanya melalui musik.

Dari tahapan survey, observasi, pengumpulan data hingga analisis data, penulis mendapatkan beberapa kesimpulan bahwa kelompok Gendang Beleq Mertaq Mi memiliki pemahaman tentang karakter ideal terhadap organologi dari segi bentuk, bahan, hingga tonalitas yang didapatkan. Kedua adalah penulis mendapatkan informasi tentang fungsi instrumen, fungsi musikal, teknik dekoratif, dan aspek sosial budayanya terkait dengan obyek material.Hal ini tentu juga bermanfaat bagi pembelajaran dasar untuk anak SD, SMP, SMA, hingga Perguruan Tinggi tentang pemahaman instrumentasi dan organologi sebelum mereka belajar gending secara langsung. Memang kajian ini sangat jarang dilakukan karena baru muncul di beberapa daerah seperti Jawa dan Bali. Sedangkan NTB belum sama sekali. Dengan adanya riset awal ini, diharapkan kesadaran tentang upaya melestarikan gendang beleq secara pemahaman instrumentasi dan organologi semakin ditindaklanjuti oleh beberapa pihak yang terkait dengan persoalan Gendang Beleq.

Instrumentasi dan organologi Gendang Beleq hanya secuil kajian yang bersifat pendokumentasian terhadap kesenian ini. Masih banyak ruang yang perlu dilakukan penelitian untuk mengumpulkan dan mencatatkan berbagai macam pengetahuan Gendang Beleq yang kemudian di masa mendatang akan dapat disatukan sebagai bentuk sumber literatur. Sumber pembacaan bagi generasi mendatang untuk dapat digunakan sebagai rujukan dan memudahkan masyarakat di dalam mengenali, memahami, dan juga mempelajari kesenian Gendang Beleq.

\section{DAFTAR PUSTAKA}

Abdoellah, Oekan S. 2017. Ekologi Manusia dan Pembangunan Berkelanjutan. Jakarta: PT Gramedia Pustaka Utama.

Hood, Mantle. 1982. The Ethnomusikologist. Ohio: The Kent State Universitity Press.

Merriam, Alan P. 1964. The Antropology of Music, Illionis. North-western: University Press.

Moleong, Lexy J. 2005. Metodologi Penelitian Kualitatif. Bandung: Remaja Rosda Karya.

Nettl, Bruno. 1964. Theory and Method in Ethnomusicology. New York: The Free Press of Glencoe.

Soedarsono, R. M. 2002. Seni Pertunjukan Indonesia di Era Globalisasi. Yogyakarta: Gadjah Mada University Press.

Yudarta, I Gede, I Nyoman Pasek. 2015. "Revitalisasi Musik Tradisional Prosesi Adat Sasak Sebagai Identitas Budaya Sasak". Jurnal Segara Widya. Vol. 3 No. 1

Yaningsih, Sri. 1988. Peralatan Hiburan dan Kesenian Tradisional Daerah Nusa Tenggara Barat. Jakarta: Departemen Pendidikan dan Kebudayaan

Yatminah, Dwi. 2018. "Meningkatakan Aktivitas Belajar dan Kemampuan Bermain Musik Ansambel dengan Model Tutorial Sebaya Bagi Siswa Kelas VIII A SMP Murni 1 Surakarta Semester 2 Tahun 2016/2017'. Jurnal Pendidikan DWIJA UTAMA, Edisi Mei. Surakarta: Forum Komunikasi Guru Pengawas Surakarta. 